\title{
Industrial Introduction of High Technologies to Engineering Industry Plants of Republic of Tatarstan
}

\author{
Bulnina I.S. ${ }^{a}$ \\ Askhatova L.I. ${ }^{\mathrm{b}}$ \\ Kabasheva I.A. ${ }^{c}$ \\ Rudaleva I.A.d \\ a bcd Kazan Federal University, Institute of Management, Economics and Finance, Kazan, 420008, Russia \\ Email: ibulnina@gmail.com
}

\section{Doi:10.5901/mjss.2015.v6n1s3p456}

\section{Abstract}

In the current economic and political conditions of Russia's development projects is a public-private partnership can be a real tool for Quitting the difficult situation. The state represented by bodies of regional and local authorities with the help of publicprivate partnership will be able to move from direct budgetary financing of projects to a promising model for attracting private funds, thereby increasing the efficiency of their operations. There is a need to strengthen the system of interaction between government and the private sector, as it will lead to the creation of conditions for increasing the competitiveness of the public sector through more effective use of state property, investment in the economy, modernization of industrial and social infrastructure, improving the quality of goods, works and services.

Keywords: public-private partnerships, project finance, money, efficiency, interaction mechanism, government, business

\section{Introduction}

As of the date of Russian economic growth, engineering industry plants are in a position to produce high-technology competitive products only for narrow world market segments. Actual status of engineering industry does not allow Russian high-technology products to entry into the world market and occupy stable market niches, to a greater extent, by virtue of default in tasks and objectives of economical competitive growth in the long run.

Machine-building complex must inherently dominate in state economic sectors and impact enhancing innovational orientation of almost all fields that is why innovative development of Russian engineering is the major task for economic development. In addition, it should be appreciated that in consequence of inadequate state-of-the-art and current local trends, it is a great challenge to implement simultaneous technological re-equipping of all strategic manufactures in Russian machine-building complex.

However, there is a chance of innovation progress speed-up on engineering plants of Republic of Tatarstan mostly in consequence of high rates of its economic growth that, in turn, was achieved by developing of innovative sciencebased high-technology production, industrial and technology parks, deepening of trans-regional and inter-republican cooperation.

\section{Method}

Present state and prospects for the development of high technologies are considered through the example of manufacturing plants of Republic of Tatarstan. In this respect, first of all, it is logical to analyze state of manufacturing sector, and after that to investigate prospects of science-based machine-building enterprises, being manufacturing complex subsystem.

Industrial structure of manufacturing production making up $60 \%$ of overall total manufacturing sector in RT is illustrated in Figure 1. 


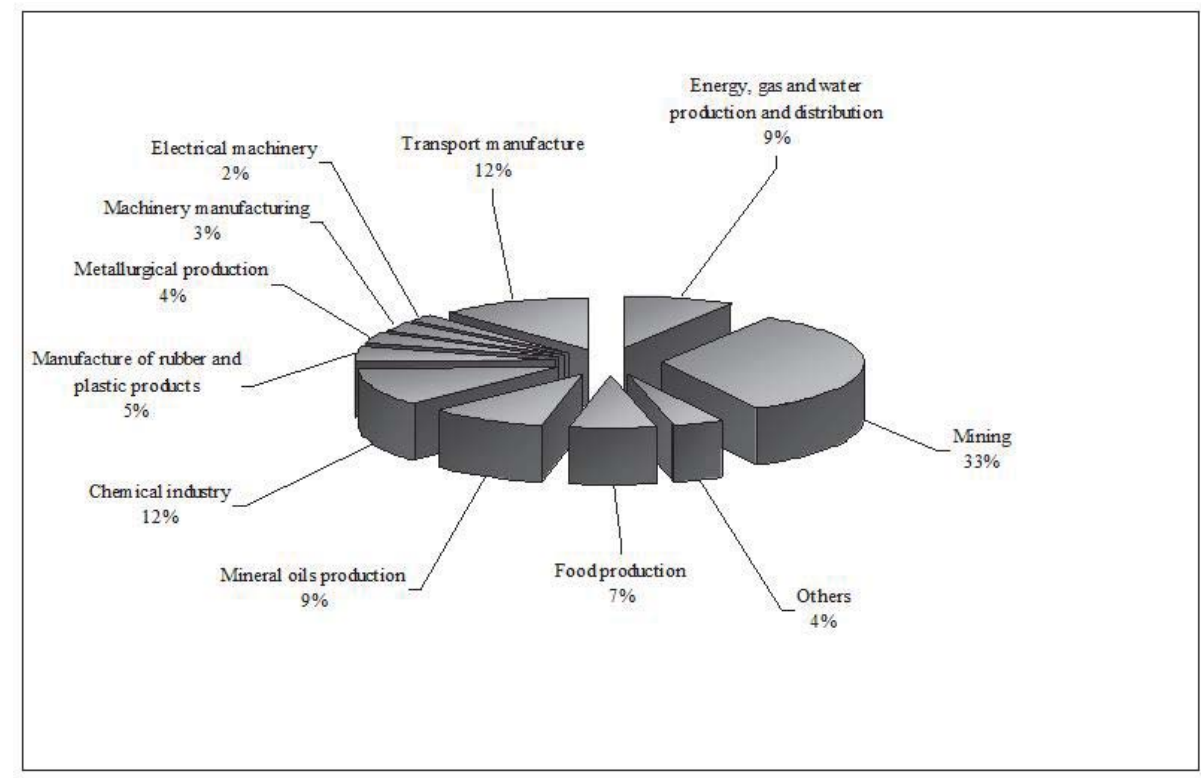

Fig.1. Structure of processing manufacturing sector in RT.

As is seen from the figure, major production fields are mining, chemical industry and transport manufacture, the share of which is $57 \%$ of overall production of manufacture in RT, and in these production fields introduction of science-based manufacturing technologies takes place.

Among key factors of innovative engineering industry development is active national policy. According to importance of supporting national priorities in science and technology development, it is necessary to specify the major task for state as assistance in development of machine-building complex.

The next key factor of innovative development of machinery production is dictated by reasonable choice of innovation strategy. Innovation strategy is one way of achieving enterprise's goals, which differs from others by its novelty, ultimately for the enterprise itself and for segment, market and consumers as probability. Innovation strategy complies with general business strategy. It defines objectives of innovation activity, choosing expedient and means of engaging sources.

There are following deterrents obtained while executing innovation strategies on manufacturing enterprises:

1. Increase in level of results uncertainty.

2. Increase in investment design risks.

3. Changes flow on the enterprise increases significantly as a result of introduction of high technologies.

One may specify long-term engineering industry development goals for Republic of Tatarstan.

- Maintaining market power in respect of current facility, technologies, gradual increase in share of selfconsumption.

- Venturing and developing of going joint enterprises;

- Creation of emerging markets, new equipment, step-by-step revolution in import tendency;

- Human resources development in engineering sector;

- Holding important positions in the world market in capacity of exporter on a range of innovative technologies.

Machine-building complex includes more than twenty sectors of precision, medium and heavy engineering. Key industries are tool engineering, power-plant engineering, shipbuilding, oil-and-gas machine building, air industry etc.

One of the main problems in engineering industry are:

1) Excess amount of old-fashion production capacities and unreasonable maintenance costs;

2) Production capacity infrastructure is out-of-date;

3) Equipment and technologies accumulated extreme wear and tear;

4) For the purpose of implementation of programs on strategic reformation there is giant lack of financial resources. Low investment and credit attractiveness of enterprises;

5) Production cooperation of industrial enterprises is carried out extremely ineffectively;

6) Skilled labour force deficiency. 


\section{Result}

Tatarstan is fully engaged in federal target programs, its enterprises implement most of investment programs with the use of own resources. In compliance with basic strategic orientation of republic economic growth set out in Program of Economic and Social Development of Republic of Tatarstan as of 2005-2010, it is essential to reinforce scope of measures concerning refocusing investment flows into science-based high-technology industries, coordination activity on innovative projects implementation in oil-and-gas, machine-building, telecommunication industries.

Prognostics of manufacturing enterprises performance implementing science-based technologies was realized inside of research based on the following cases:

- formal, assuming partial implementation of suggested methods of strategic competitiveness management, so that it achieves $30 \%$ of all effect by the end of five-year period;

- advanced, assuming almost full and consistent implementation of suggested methods of strategic competitiveness management, so that it achieves $50 \%$ of all effect by the end of five-year period;

- medium-optimistic, assuming full phase-in of suggested methods of strategic competitiveness management, so that it, as a result of deviation from a plan at implementation and realization, achieves $70 \%$ of all effect by the end of five-year period;

\section{Conclusion}

Under current conditions, it is necessary to use structural approach for manufacturing enterprise growth strategy buildup in terms of competitiveness definition; however, structuring must consider supposed strategic cut-out of manufacturing enterprise that is relevant to science-based industrial sector to the fullest extent. As can be seen from the above, it is essential to choose firmly frame of competitiveness definition for effective strategy formation of science-based manufacturing enterprise, reflecting current state, development prospects and strategic potential of economic entity, this points to the fact that it is rational to use balanced scorecard in the quality of specified frame. In addition to the above, there is a need to set particular factors batch per category, meeting needs of strategy generation for science-based manufacturing enterprise.

From all has been said follows that roadmap for innovative development of machinery production in Republic of Tatarstan is currently determined and percolates incompletely. All tools focused on effective solution of assigned tasks require significant financial investments not only in research and technology, but also into personnel training - active state participation at universities, education and enterprises cooperation are required.

\section{References}

Tapinos, E.; Dyson, R. and Meadows, M. ,2005, The impact of

performance measurement in strategic planning/International Journal of Productivity and Performance Management, Vol. 54, No. 5/6, pp. 370-384.

Klychova G.S., Zakirova A.R., Mukhamedzyanov K.Z., Faskhutdinova M.S. Management reporting and its use for information ensuring of agriculture organization management // Mediterranean Journal of Social Sciences vol. 5 № 24, November 2014, pp. 104-110

M. Dassisti, 2010,HY-CHANGE: a hybrid methodology for continuous performance improvement of manufacturing processes/ International Journal of Production Research, vol. 48, no. 15, pp. 4397-4442.

Toma Noda \& Joseph L. Bower, 1996, «Strategy making as Iterated Processes of Resource Allocation» / Strategic Management, Journal 17,pp. 159-192.

Klychova G.S., Iskhakov A.T., Valieva G.R., Klychova A.S. Functions accounting at the enterprises of dairy cattle breeding in the context of cost pool according to physiological groups // Mediterranean Journal of Social Sciences vol. 5 № 24, November 2014, pp. 98103

Melnik A.N., Ermolaev K.A., Antonova N.V.Stages in Formalizing Energy Conservation and Efficiency Management in Industrial Enterprises// Mediterranean Journal of Social Sciences.- Vol.5, No12, (2014)-pp.173 - 176.

Oswaldo A. N. Borges de Menezesa Brazilian ,2010, Manufacturing Strategies in Action /Brazilian Journal of Operations \& Production Management, Volume 7, Number 1, pp. 09-35

Baranov E., 2012. Complex strategy enterprise/ Scientific paper series: Management, Economic engeneering , Volume 12, Issue 2, pp. 171-186.

Proiect CNCSIS-consortiu, 2008, „Modeleşimetodecomplexe de cercetareîndezvoltarearuralădurabilă a Romaniei”, IEA.Jagpal, S., M.Spiegel. 2011. Free samples, profits, and welfare: The effect of market structures and behavioral modes. /Journal of Business Research, Volume 64, Issue 2, pp. 213-219.

Askhatova L.I., Fatkhiev A.M., Safiullin L.N. and Safiullina A.M. Competitive Strategies Formation in High Technology Enterprise // World 
Applied Sciences Journal, 27(13), 2013, pp. 20-23.

Sousa, S.; Aspinwall, E. and Rodrigues, A., 2006, Performance measures in English small and medium enterprises: survey results/ Benchmarking: An International Journal, Vol. 13, No. 1/2, pp. 120-134.

Azoev G. L., 2000 Konkurentnyepreimushchestvafirmy [The competitive advantages of firms] / G. L. Azoev, L.P. Chelenkov. -M., 2000. $-256 \mathrm{p}$.

Melnik, A.N., Dyrdonova, A.N. (2014). Infrastructural support for development of the territorial petrochemical cluster. Mediterranean Journal of Social Sciences, 5 (18 SPEC. ISSUE), pp. 299-304. 